\title{
Risk of encounters between North Atlantic right whales and recreational vessel traffic in the southeastern United States
}

\author{
Nancy L. Montes ${ }^{1}, \underline{\text { Robert Swett }}^{2}$ and Timothy A. Gowan ${ }^{3}$
}

\begin{abstract}
Collisions with and disturbance from watercraft represent significant threats to endangered North Atlantic right whales (Eubalaena glacialis). Although several studies have investigated whale cooccurrence with commercial vessels, none has considered recreational vessels. We estimated an index between relative encounter risk of North Atlantic right whales and recreational vessel traffic in the southeastern USA calving grounds. Sightings of recreational vessels and right whales were recorded during aerial surveys in 2009-2014. We use generalized additive models to estimate relative occurrence of recreational vessels in the study area. We used estimates of relative North Atlantic right whale occurrence from Gowan and Ortega-Ortiz (2014). Results suggest that areas with elevated relative encounter risk were concentrated near navigable inlets. Additionally, temporal variability in these probabilities was influenced more by the spatial migratory patterns of North Atlantic right whales than by the distribution of recreational vessels. Our results can be used to inform the conservation of the North Atlantic right whales by identifying and mitigating areas with high risk of recreational vessel disturbance and collisions.
\end{abstract}

Key Words: distribution; encounter risk; North Atlantic right whales; recreational vessels

\section{INTRODUCTION}

The North Atlantic right whale (Eubalaena glacialis) is an endangered species with an estimated population of 465 individuals (Pettis et al. 2018). Their only known calving grounds are the coastal waters of the southeastern United States (SEUS). This region also experiences a large amount of vessel traffic from different sources (e.g., military bases, shipping ports, commercial and recreational vessels), resulting in potential encounters between North Atlantic right whales and these vessels. Although previous studies have estimated the relative probability of encounter between North Atlantic right whales and commercial ships that are 300 gross tons or greater (Ward-Geiger et al. 2005, Fonnesbeck et al. 2008, Vanderlaan et al. 2009, Lagueux et al. 2011), information about the spatial distribution and overlap of recreational vessels ( $<20 \mathrm{~m}$ in length) with North Atlantic right whales is limited. Collisions with vessels $<20 \mathrm{~m}$ have been documented for several large whale species, including the North Atlantic right whale, and have the potential to be fatal (Laist et al. 2001).

Although collisions with vessels are a leading cause of mortality for the North Atlantic right whale (Sharp et al. 2019), other shortand long-term effects of vessel activities on North Atlantic right whales are less understood, especially for smaller, recreational vessels and within the calving ground of these whales. However, previous studies have shown that vessel-related activities could displace whales (Salden 1988, Smultea 1994, Rowntree et al. 2001) and modify their short-term behavior (e.g., decreasing resting and socializing time and increasing traveling time) (Vermueulen et al. 2012, Lundquist et al. 2013). It has been documented that changes in cetacean behaviors were more noticeable and frequent as the number of vessels increased and their approaches to whales became closer (Lusseau 2005, Haviland-Howell et al. 2007, Timmel et al. 2008, Chion 2011, Pennino et al. 2016). Rolland and others (2012) documented chronic stress of right whales in the Bay of Fundy due to low-frequency ship noise and Watkins (1986) reported uninterested or negative reactions of right whales toward boat traffic near Cape Cod. Additionally, several studies found that cow/calf pairs in some cetacean species exhibit a spatial preference for areas closer to shore and in shallower waters, which could increase their exposure to anthropogenic activities (Smultea 1994, Elwen and Best 2004, Félix and Botero 2011). Significantly, Montes et al. (2016) estimated that over 5000 recreational vessels are active in the northeast Florida and southeast Georgia region of the SEUS during winter months (from December to March) when North Atlantic right whales are present.

Numerous regulatory measures are in place to mitigate whale disturbance by vessels (especially for lactating mothers and calves). The rule of greatest importance to recreational boaters [62 FR 6729] makes it illegal to approach and remain within 460 $\mathrm{m}$ (500 yards) of North Atlantic right whales. During the time of this study, almost half of recreational boaters $(47 \% ; n=359)$ said they had seen right whales while boating or from the beach, and more than half $(65 \% ; n=355)$ were aware of the $460 \mathrm{~m}$ rule (Montes et al. 2018b). Nevertheless, quantitative estimates of North Atlantic right whale/recreational vessel encounters are scarce, and little is known about their spatial and temporal distribution. Consequently, the focus of this study was to estimate relative probabilities of North Atlantic right whale/recreational vessel cooccurrence in the SEUS and identify, by month, areas of overlap between North Atlantic right whales and recreational vessels. We identified areas where North Atlantic right whales and recreational vessels are prone to cooccur (representing an index of relative encounter risk) by modeling aerial sighting counts of North Atlantic right whales and recreational vessels based on explanatory variables thought to influence their distribution.

\footnotetext{
${ }^{1}$ Florida Sea Grant College Program, University of Florida, ${ }^{2}$ Fisheries and Aquatic Sciences Program, School of Forest Resources and Conservation, University of Florida, Gainesville, Florida, USA (Retired), ${ }^{3}$ Florida Fish and Wildlife Conservation Commission, Fish and Wildlife Research Institute, St. Petersburg, Florida, USA
} 


\section{METHODS}

Study area and data collection

Relative likelihoods of North Atlantic right whale and recreational vessel cooccurrence within the SEUS were estimated. The study area comprised $13,702 \mathrm{~km}^{2}$ and ranged from approximately $31^{\circ} 34^{\prime} \mathrm{N}$ to $29^{\circ} 46^{\prime} \mathrm{N}$ in northing and $81^{\circ} 18^{\prime} \mathrm{W}$ to $80^{\circ} 29^{\prime} \mathrm{W}$ in easting (Fig. 1).

Fig. 1. Study area including Early Warning System (EWS) aerial survey track lines and the sampling grid cells used for the analyses. The image includes the designated critical habitat of the North Atlantic right whale in the southeast United States, and the sampling grid cells are $5.56 \times 5.56 \mathrm{~km}$ cells $(n=441)$. Bathymetric depth contours (in $100 \mathrm{~m}$ increments).

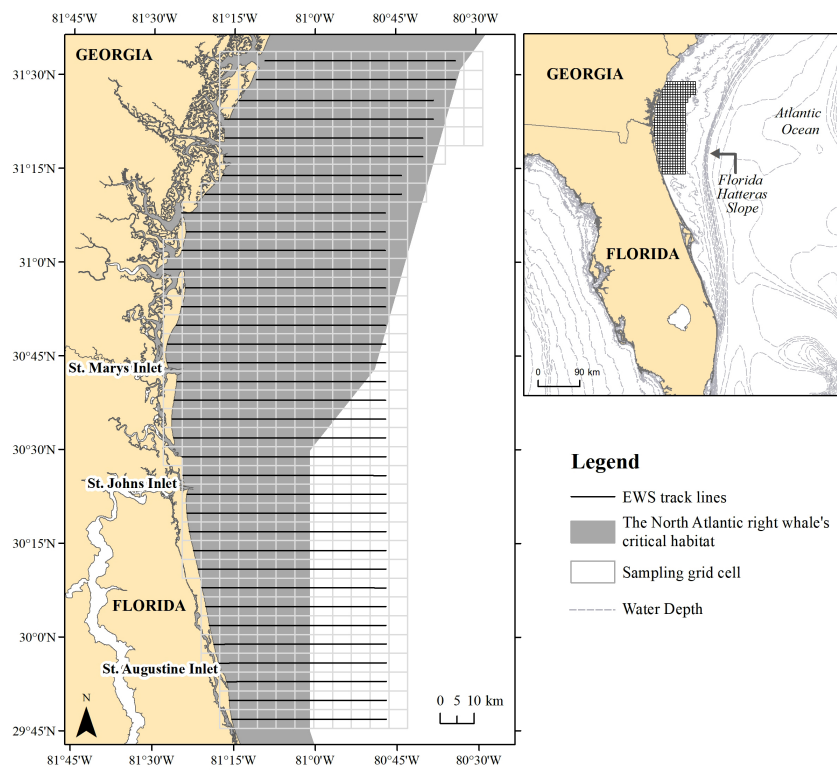

For our analyses, we used data collected by the Early Warning System (EWS) during the winter seasons (December through March) of 2009-2014. The EWS, an extensive network of aerial surveys flown in the SEUS North Atlantic right whale calving and nursing grounds, provided daily spatial and temporal information about the locations of North Atlantic right whales and recreational vessels in the study area. During this study, the EWS flew parallel, east-west track lines that were, generally, 5.56 km apart (see Gowan and Ortega-Ortiz 2014 for details; Fig. 1). Surveys were only flown in favorable weather conditions, targeting a visibility of at least $3.7 \mathrm{~km}$ and a Beaufort sea state of 3 or less. The surveys were designed such that observers (one on each side of the plane) recorded the locations of North Atlantic right whale (s) with greater precision than that of recreational vessels. When a North Atlantic right whale was sighted, the plane veered from its track line to fly directly over the animal(s) and record the coordinates. In contrast, observers only recorded the number of recreational vessels within a distance of $2.78 \mathrm{~km}$ on each side of the current (recorded) position of the plane as it maintained course on the track line. Marks indicating a distance of $2.78 \mathrm{~km}$ from the plane at the target survey altitude $(305 \mathrm{~m})$ were placed on the plane struts to aid in estimating this distance. Vessels beyond $2.78 \mathrm{~km}$ were not recorded, and it is assumed that all recreational vessels within $2.78 \mathrm{~km}$ were detected. One limitation of the data set is that there is no information identifying individual vessels, and therefore, it is not possible to determine if a vessel was observed multiple times. For the purpose of this study, recreational vessels comprise open fishing (center-console) boats, runabouts (speed boats, Cigarette, Scarab, etc.), offshore sport fishing boats, sailboats, charter and head boats, and yachts. In 2012, we estimated that the average length of recreational vessels transiting the area during the North Atlantic right whale calving season was $8 \mathrm{~m}$ (range $=4-21 \mathrm{~m}, n=311)$ (Montes et al. 2016). To account for disparities in the study area and sampling constraints, a grid $(5.56 \times 5.56 \mathrm{~km}$ cells $)$ was overlaid onto the study area in ArcGIS 10.6 (Environmental Systems Research Institute (ESRI) 2018). The grid was designed such that an aerial track line bisects each of the grid cells in the study area and such that each cell was exactly twice the $2.78 \mathrm{~km}$ distance within which observers were asked to detect vessels (Fig. 1). For all the geographic layers, we used an equidistant Universal Transverse Mercator (UTM) projection.

\section{Data analysis}

We used estimates of relative North Atlantic right whale occurrence from Gowan and Ortega-Ortiz (2014). They found that the probability of observing a North Atlantic right whale could be modeled using sea surface temperature (SST), water depth, survey year, distance to shore, distance to the $22^{\circ} \mathrm{C} \mathrm{SST}$ isotherm, and an interaction between time of year (i.e., semimonthly period) and northing (see Gowan and Ortega-Ortiz 2014 for details). Estimates of relative North Atlantic right whale occurrence probability were produced for semimonthly (approximately 2-week) periods. However, we averaged these semimonthly estimates within each month to fit the monthly temporal resolution of the current study.

Monthly estimates of recreational vessel abundance were obtained using generalized additive models (GAMs) applied to vessel sightings and explanatory variables that were selected based on previous studies. Three groups of explanatory variables were used (Table 1). Because there are only a limited number of access points to offshore waters (Fig. 1), we expected geographic location (in the form of northing, easting, and the Euclidean distance from each grid cell centroid to the center of the nearest inlet mouthSt. Marys, St. Johns, or St. Augustine Inlets) to have an important role in describing the distribution of offshore recreational vessels (Sidman and Fik 2005, Bauduin et al. 2013, Montes et. al. 2018a). Fishing is the leading activity of recreational vessels in Florida, and recreational vessel distribution has been linked with the distribution of target fish species. Sidman et al. (2007) found that $73 \%$ of recreational boaters in Brevard County (adjacent to our study area) engaged in fishing activities. Some studies found a link between concentrations of chlorophyll $a$, SST, and fishery yields (Wall et al. 2009, Chang et al. 2012, Radlinski et al. 2013, Farrel et al. 2014). Artificial reefs have also been shown to influence the distribution of recreational anglers because they increase fishing opportunities (Buchanan 1973, Bohnsack and Sutherland 1985, Bohnsack 1989). Popular fish species targeted by recreational anglers in the study area are red drum, spotted seatrout, kingfish, mahimahi, spot, Spanish mackerel, bluefish, Atlantic croaker, yellowtail snapper, and black sea bass (National Oceanic and 
Atmospheric Administration (NOAA) Fisheries, unpublished factsheet: https://www.fisheries.noaa.gov/resource/educationalmaterials/south-atlantic-saltwater-recreational-fisheries-snapshot). Therefore, we related observed abundance of recreational vessels to proxies for fish distribution, including SST, chlorophyll $a$ concentration, water depth, and abundance of artificial reefs. Survey year and month were included to account for inter- and intraannual variation in recreational vessel abundance. Survey effort was also included as a variable influencing the number of vessels observed. When the dependent variable in a model is a count variable (nonnegative integer), sampling effort can be included in the model as an offset variable, which assumes a linear relationship between sampling effort and counts with a coefficient of 1 (Wood 2006, Zuur 2012). In our case, this assumption was not met (see Results), and therefore, we used sampling effort as a smoothed covariate. The explanatory variables were introduced in the competing models as centered values (value - mean) when applicable. To assess for collinearity among explanatory variables, Pearson's correlation estimates were produced in R software using the PerformanceAnalytics package (Peterson et al. 2018), and correlated variables $(r>0.7)$ were not included in the same models (Dormann et al. 2013). Model selection was determined by Akaike information criterion corrected for small sample size (AICc). The MuMIn package (Barton and Barton 2015) was used to obtain AICc values and AICc weights.

Table 1. Explanatory variables assessed to predict the relative abundance of recreational vessels in the study area

\begin{tabular}{|c|c|c|}
\hline Variable & Source & Description \\
\hline \multicolumn{3}{|c|}{ Geographic variables } \\
\hline Northing & Sampling grid & Northing of centroid of each grid cell. \\
\hline Easting & Sampling grid & Easting of centroid of each grid cell. \\
\hline $\begin{array}{l}\text { Distance to } \\
\text { the nearest } \\
\text { inlet }\end{array}$ & Sampling grid & Distance from centroid of each grid cell. \\
\hline \multicolumn{3}{|c|}{ Proxy for fish distribution } \\
\hline SST & $\begin{array}{l}\text { Terra and } \\
\text { Aqua }\end{array}$ & $\begin{array}{l}\text { Sea surface temperature }(4 \mathrm{~km}) \text { derived } \\
\text { from short-wave }(11-12 \mu \mathrm{m}) \text { thermal } \\
\text { radiation. }\end{array}$ \\
\hline $\begin{array}{l}\text { Chlorophyll } \\
a\end{array}$ & $\begin{array}{l}\text { Terra and } \\
\text { Aqua }\end{array}$ & $\begin{array}{l}\text { The concentration of the near-surface } \\
\text { photosynthetic pigment chlorophyll } a \text { (4 } \\
\mathrm{km}) \text {. }\end{array}$ \\
\hline Water depth & $\begin{array}{l}\text { NOAA } \\
\text { National } \\
\text { Center for } \\
\text { Environmental } \\
\text { Information }\end{array}$ & $\begin{array}{l}\text { Ocean depths (means). Third Arc-Second } \\
\text { resolution (approximately } 10 \mathrm{~m} \text { ). }\end{array}$ \\
\hline $\begin{array}{l}\text { Artificial } \\
\text { reefs }\end{array}$ & $\begin{array}{l}\text { Florida } \\
\text { Geographic } \\
\text { Data Library }\end{array}$ & $\begin{array}{l}\text { Abundance of artificial reefs per grid cell. } \\
\text { Artificial reefs is a point layer depicting the } \\
\text { location where the artificial reef was } \\
\text { deployed. }\end{array}$ \\
\hline \multicolumn{3}{|c|}{ Sampling variables } \\
\hline Year & Aerial surveys & $\begin{array}{l}\text { Categorical variable to represent the year of } \\
\text { data collection. In the study area, surveys } \\
\text { occur from December-March. }\end{array}$ \\
\hline Month & Aerial surveys & $\begin{array}{l}\text { Categorical variable to represent the month } \\
\text { of data collection. }\end{array}$ \\
\hline Effort & Aerial surveys & $\begin{array}{l}\text { Length of daily aerial survey tracks, } \\
\text { summed by month and multiplied by } \\
\text { survey strip width }(5.56 \mathrm{~km}) \text { in each grid } \\
\text { cell. }\end{array}$ \\
\hline
\end{tabular}

Relationships between recreational vessel sightings and environmental covariates were modeled with GAMs using a negative binomial distribution and logit link in $\mathrm{R}$ software using the $m g c v$ package (Wood 2001). Poisson, hurdle, and zero-inflated models were also tested, but we found them less appropriate based on the overdispersion of residuals. For the GAMs, a penalty term was added to the regression to control for the smoothness of the fitted curve and avoid overfitting (Wood 2006). The smoothness selection was fit using spline-based penalized likelihood estimation with the restricted maximum likelihood (REML) method (Wood 2006), and forward model selection was carried out using the double penalty approach to smooth and remove irrelevant covariates from the model (Marra and Wood 2011). Overdispersion of the residuals for each competing model was assessed using the overdispersion function in $m g c v$ (Zuur 2012). Autocorrelation of residuals was estimated using the gstat package (Pebesma 2004). Once we had selected the best-fit GAM, we used it to predict the abundance of recreational vessels across the gridded study area.

We modified the approach used by Vanderlaan et al. (2009) to obtain monthly estimates of the relative probability $\left(P_{\text {rel }}\right)$ that a whale (Eq. 1) and a recreational vessel (Eq. 2) occupied a specific grid cell $i$ :

$$
\begin{aligned}
& P_{\text {rel }}(\text { Whale })_{i}=\frac{\text { Predicted relative whale abundance }}{i} \\
& \sum_{i=1}^{n} \text { Predicted relative whale abundance } e_{i}
\end{aligned}
$$

Monthly estimates of the relative probability of North Atlantic right whale and recreational vessel occurrence were multiplied, then normalized so that the sum across the study area was 1 , to obtain an index of relative encounter risk (Eq. 3):

$$
P_{\text {rel }}(\text { Encounter })_{i}=\frac{P_{\text {rel }}(\text { Whale })_{i} * P_{\text {rel }}(\text { Recreational vessel })_{i}}{\sum_{i=1}^{n} P_{\text {rel }}(\text { Whale })_{i} * P_{\text {rel }}(\text { Recreational vessel })_{i}}
$$

Maps displaying the monthly index of relative encounter risk were generated using ArcGIS Pro. Direct observations of North Atlantic right whale/vessel interactions (cooccurrence) were recorded by the EWS during surveys. These interaction reports are considered conservative estimates, as they consist of presenceonly data and are limited to times and areas with survey effort, but their locations were overlaid on maps of model-predicted relative encounter risk for qualitative comparison.

\section{RESULTS}

Overall, during 316 survey flights conducted from December 2009 to March 2014, there were more recorded sightings of recreational vessels (5467 sightings) than of North Atlantic right whales (1038 sightings). Recreational vessel sightings exhibited a negative binomial distribution. The number of grid cells with zero counts did not exceed the expected number based on the theoretical negative binomial distribution ( $p=0.28$, chi-squared goodness of fit test).

\section{Relative abundance of recreational vessels}

Northing, easting, distance to the nearest inlet, abundance of artificial reefs, SST, chlorophyll $a$ concentrations, water depth, survey effort, winter (year), and month were significantly 
Table 2. Model selection of recreational vessel relative abundance. Covariates included: $x=$ easting, $y=$ northing, $x: y=$ interaction term between easting and northing, inlet $=$ distance to the nearest inlet, $\mathrm{y}$ :inlet $=$ interaction term between northing and inlet, reef $=$ reef abundance per sampling unit, depth $=$ bathymetry, $\mathrm{y}:$ depth $=$ interaction term between latitude and depth, effort $=\mathrm{km}^{2}$, survey year $=$ winter of survey, month $=$ data collection month, sst $=$ sea surface temperature, chlo $=$ chlorophyll $a$ concentrations, and $\mathrm{K}=$ number of parameters.

\begin{tabular}{|c|c|c|c|c|c|c|c|c|c|c|c|c|c|c|c|c|c|c|c|}
\hline $\mathrm{x}$ & $\mathrm{y}$ & $\mathrm{x}, \mathrm{y}$ & inlet & $\mathrm{y}$, inlet & reef & effort & year & month & sst & chlo & depth & $y$, depth & $\begin{array}{l}\text { Deviance } \\
\text { explained }\end{array}$ & $\operatorname{Adj} R^{2}$ & $\begin{array}{l}\text { Overdispersion } \\
\text { of residuals }\end{array}$ & $\mathrm{K}$ & $\mathrm{AICc}$ & $\begin{array}{l}\text { Delta } \\
\text { AICc }\end{array}$ & $\begin{array}{l}\text { AICc } \\
\text { Weight }\end{array}$ \\
\hline & 1 & & $\mathrm{~s}$ & $\mathrm{~s}$ & $\mathrm{~s}$ & $\mathrm{~s}$ & $\mathrm{~s}$ & $\mathrm{~s}^{*}$ & $\mathrm{~s}$ & & & & $58.3 \%$ & 0.40 & 1.16 & 54 & 13932 & 0 & 0.86 \\
\hline & s & & s & s & s & s & s & $\mathrm{s}$ & s & & & & $58.3 \%$ & 0.40 & 1.16 & 56 & 13935 & 3.6 & 0.14 \\
\hline & s & & $\mathrm{s}$ & $\mathrm{s}$ & s & $\mathrm{s}$ & $\mathrm{s}$ & s & s & s & & & $58.2 \%$ & 0.37 & 1.12 & 61 & 13953 & 21.3 & 0 \\
\hline & s & & s & $\mathrm{s}$ & s & $\mathrm{s}$ & $\mathrm{s}$ & s & & & & & $57.9 \%$ & 0.37 & 1.19 & 52 & 13965 & 33.0 & 0 \\
\hline & $\mathrm{s}$ & & 1 & $\mathrm{~s}$ & $\mathrm{~s}$ & $\mathrm{~s}$ & $\mathrm{~s}$ & s & s & & s & & $57.1 \%$ & 0.21 & 1.17 & 59 & 14045 & 113.3 & 0 \\
\hline \multirow[t]{4}{*}{ s } & s & s & & & $\mathrm{s}$ & $\mathrm{s}$ & $\mathrm{s}$ & s & s & & & & $57.0 \%$ & 0.19 & 1.25 & 64 & 14063 & 130.9 & 0 \\
\hline & s & & & & $\mathrm{s}$ & $\mathrm{s}$ & $\mathrm{s}$ & s & $\mathrm{s}$ & s & s & s & $56.9 \%$ & 0.22 & 1.11 & 59 & 14064 & 131.7 & 0 \\
\hline & $\mathrm{s}$ & & 1 & $\mathrm{~s}$ & $\mathrm{~s}$ & $\mathrm{~s}$ & $\mathrm{~s}$ & $\mathrm{~s}$ & & & $\mathrm{~s}$ & & $56.8 \%$ & 0.19 & 1.20 & 56 & 14068 & 135.7 & 0 \\
\hline & $\mathrm{s}$ & & 1 & $\mathrm{~s}$ & $\mathrm{~s}$ & $\mathrm{~s}$ & $\mathrm{~s}$ & $\mathrm{~s}$ & $\mathrm{~s}$ & & & & $56.4 \%$ & 0.24 & 1.15 & 51 & 14094 & 162.5 & 0 \\
\hline \multirow[t]{2}{*}{$\mathrm{s}$} & $\mathrm{s}$ & $\mathrm{s}$ & & & $\mathrm{s}$ & $\mathrm{s}$ & $\mathrm{s}$ & $\mathrm{s}$ & $\mathrm{s}$ & s & & & $56.5 \%$ & 0.22 & 1.14 & 59 & 14097 & 165.0 & 0 \\
\hline & $\mathrm{s}$ & & 1 & $\mathrm{~s}$ & s & $\mathrm{s}$ & $\mathrm{s}$ & s & & & & & $56.0 \%$ & 0.22 & 1.18 & 48 & 14123 & 191.2 & 0 \\
\hline \multirow[t]{3}{*}{ s } & $\mathrm{s}$ & $\mathrm{s}$ & & & $\mathrm{s}$ & $\mathrm{s}$ & $\mathrm{s}$ & $\mathrm{s}$ & & & & & $55.9 \%$ & 0.20 & 1.17 & 55 & 14139 & 206.8 & 0 \\
\hline & & $\mathrm{s}$ & & & $\mathrm{s}$ & $\mathrm{s}$ & $\mathrm{s}$ & $\mathrm{s}$ & & & & & $54.1 \%$ & 0.13 & 1.19 & 46 & 14280 & 348.2 & 0 \\
\hline & & & & & & & & & & & & & $0 \%$ & 0.00 & 18.19 & 1 & 18931 & 4998.7 & 0 \\
\hline
\end{tabular}

$\mathrm{s}=$ smooth term; $1=$ linear term. *not significant at $p<0.1$.

correlated with recreational vessel sightings. However, Pearson's correlation estimates indicated that some of these variables were correlated with each other. For instance, distance to the nearest inlet and water depth were highly correlated with longitude ( $r=$ 0.94, and $r=-0.78$, respectively). To avoid issues of multicollinearity, these correlated variables were not included in the same models. Instead, we compared the model fit using the AIC corrected for small sample size (AICc) by including them separately (Table 2).

The best model included distance to the nearest inlet, northing, an interaction term between distance to the nearest inlet and northing, abundance of artificial reefs, SST, survey effort, year, and month (Table 2). Although, month was not a significant variable $(p>0.05)$, we decided to leave it in the model, so that both vessels and whales are modeled over the same temporal scale. No statistically significant spatial autocorrelation was observed in the variogram of the residuals (Moran's $\mathrm{I}=-0.003, p=0.51$ ).

Figure 2 shows the fitted smooth function for each of the covariates included in the final model. Most of the significant environmental and geographical variables in the final model exhibited a nonlinear relationship with vessel density (except for northing). Models that included distance to the nearest inlet showed better fit than those with the northing or water depth variables at this spatial scale (Table 2).

Recreational vessel abundance was predicted to be highest between northings that encompass the three Inlets, in locations close to the Inlets, and in warmer SST (Fig. 2). Recreational vessel abundance was also predicted to increase with artificial reef abundance, however, the confidence interval also increased (Fig. 2). Survey effort was positively associated with recreational vessel sightings up to $2000 \mathrm{~km}^{2}$ of effort; beyond that, the influence reaches its asymptote (Fig. 2). Estimated recreational vessel abundance was lower in 2012-2013 than in other winters and higher in March during all years than in other studied months (Fig. 2).
The highest estimates of recreational vessel abundance were near and east of the three navigational inlets in the study area (St. Marys, St. Johns, and St. Augustine). The predicted number of recreational vessels was consistently higher in areas near St. Johns Inlet (Fig. 3). In March, we predicted the highest density compared with other months, and with recreational vessels distributed farther offshore (Fig. 3) toward the Florida-Hatteras slope (Fig. 1). As reference, Fig. 3 includes the monthly predicted relative probability of occurrence of North Atlantic right whales from Gowan and Ortega-Ortiz (2014).

\section{Index of relative encounter risk of North Atlantic right whales and recreational vessels}

There were no statistically significant differences between months for the index of relative encounter risk $(F=0.09 ; p=0.96)$. Geographically, areas near the main Inlets in the study area (St. Marys, St. Johns, and St. Augustine) showed the greatest relative encounter risk values, particularly around and east of St. Johns Inlet (Fig. 4). Relative encounter risk generated by the model was generally in agreement with the locations of opportunistic North Atlantic right whale/vessel interaction reports, especially with respect to areas around and east of St. Johns Inlet (Fig. 4).

\section{DISCUSSION}

\section{Relative recreational vessel abundance}

Most literature on the cooccurrence of North Atlantic right whales and vessel traffic focuses on commercial vessels that are 300 gross tons or greater. These studies are facilitated by the availability of spatial and temporal data (e.g., locations, speeds, routes) for commercial vessels through mandatory ship reporting systems (Ward-Geiger et al. 2005, Fonnesbeck et al. 2008, Vanderlaan et al. 2009, Williams and O'Hara 2010, Lagueux et al. 2011). Similar data for recreational vessels are not readily available because they are not subject to analogous reporting requirements. In addition, commercial ship distribution may be less random and, hence, more predictable than recreational vessels, which engage in a greater diversity of boating destinations 
Fig. 2. Smoothed curves of the additive effects of covariates from the best-fit model explaining the relative abundance of offshore recreational vessels in the SEUS. Predictor variables include northing (y), distance of grid centroids to the nearest inlet (Inlet), sea surface temperature (SST), Chlorophyll $a$ (Chlo a), abundance of artificial reefs (Reef), aerial surveys effort (Effort), survey year, and survey month (Month). Solid lines depict estimates of the smooth function and dotted lines indicate $95 \%$ confidence bands.
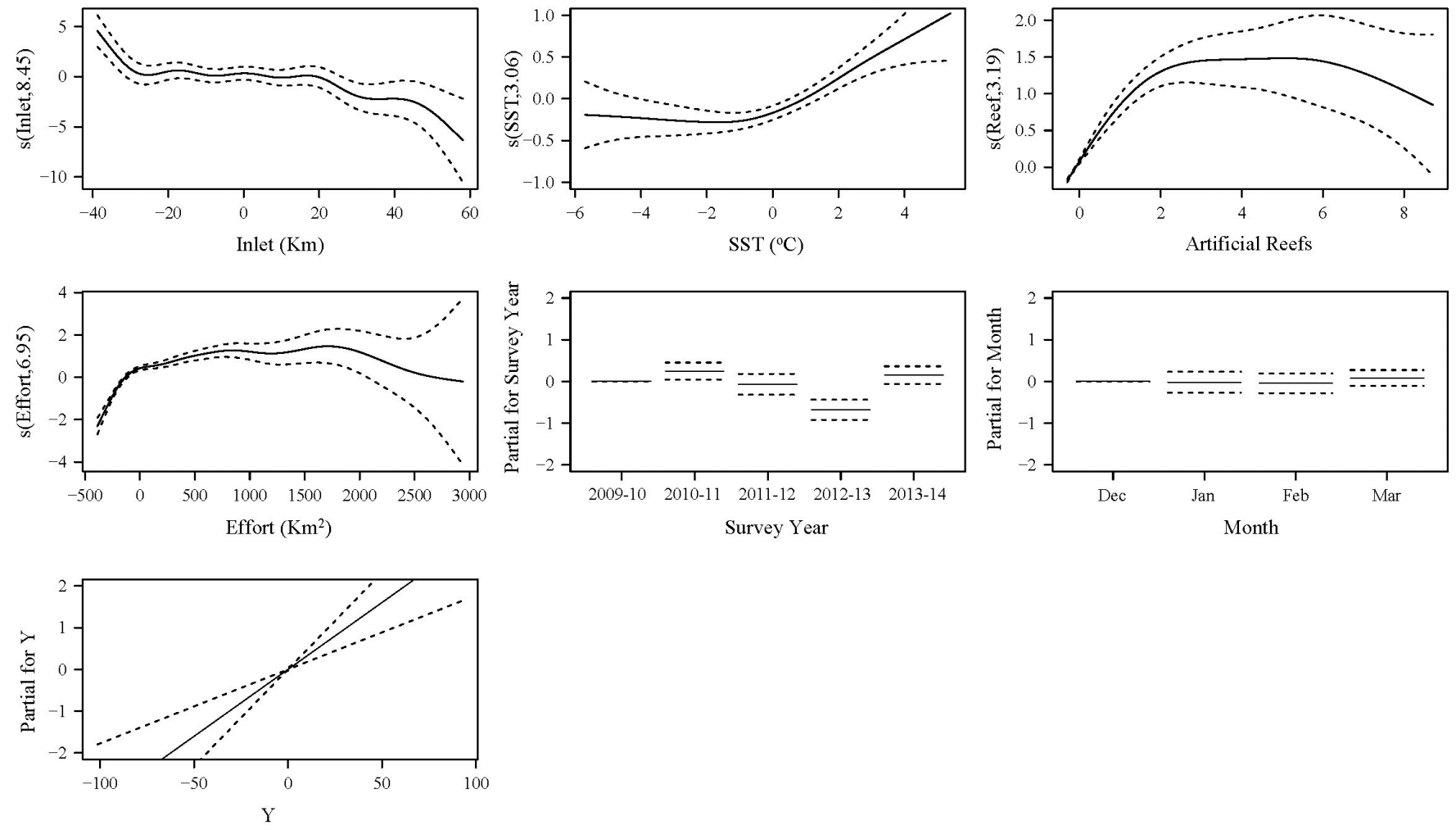

(e.g., specific water depths, known fishing spots, artificial reefs) and activities (e.g., fishing, transiting, diving). The large share of recreational boats in overall vessel traffic highlights the importance of understanding and mitigating their impacts when managing shared resources in coastal environments.

At this scale (monthly estimates), our results indicate that geographic (i.e., distance to the nearest inlet, northing) and sampling (i.e., effort, survey year) variables were significant predictors of observed recreational vessel abundance. Other recreational vessel models that used different sampling techniques and scales also found that geographic variables can be used to explain the spatial distribution of vessels (Sidman and Fik 2005, Montes et al. 2018b). The significance of year may be related to temporal variation in weather or socioeconomic factors that influence boating activity. Not all of the variables categorized as proxies for fish distribution were significant (only abundance of artificial reefs and SST). Such variables may be sensitive to the temporal or spatial scale of the study. In the case of SST, it may be influenced by or highly correlated with other variables not included in this study. For instance, Maloney and Chelton (2006) and Shimada and Kawamura (2006) found a correlation between SST and sea surface wind, and wind conditions are likely to influence the abundance and distribution of recreational vessels on the water.
Areas with high recreational vessel abundance were near the inlets (especially St. Johns Inlet). Recreational vessels also tended to be distributed along an angle perpendicular to the St. Johns and St. Augustine Inlets. This pattern seems related to deeper-sea destinations associated with the Florida-Hatteras slope (Fig. 1), where deep-sea corals and certain target fish species are common (Hourigan et al. 2017). This could indicate that, rather than relying on changing or dynamic cues (that may also be correlated with each other), recreational boaters' movements through the area are based mainly on inlet locations and known fishing spots that may be associated with target fish species and/or boating activities. However, future studies should also explore the role of other external variables such as weather conditions, sea state, and wind speed on predicting the abundance and distribution of recreational vessels.

\section{Index of relative encounter risk}

Our results suggest that the highest estimates of a whale and a recreational vessel cooccupying a specific area are located near and east of the three major inlets in the study area. Monthly estimates produced by the modeling method showed consistent high values near and east of the inlets from December to March. The index of encounter risk estimated by the modeling method for March was higher than expected for the southern portion of the study area (Fig. 4D), given that many North Atlantic right whales are expected to have started their migration north to 
Fig. 3. Choropleth maps showing the geometrical interval distribution of monthly recreational vessel abundance predicted by the best-fit GAM (top panel) and North Atlantic right whale relative abundance based on model produced by Gowan and Ortega-Ortiz (2014; lower panel). December (A), January (B), February (C), and March (D). Sampling grid cells are $5.56 \times 5.56 \mathrm{~km}$ cells $(n=$ 441).
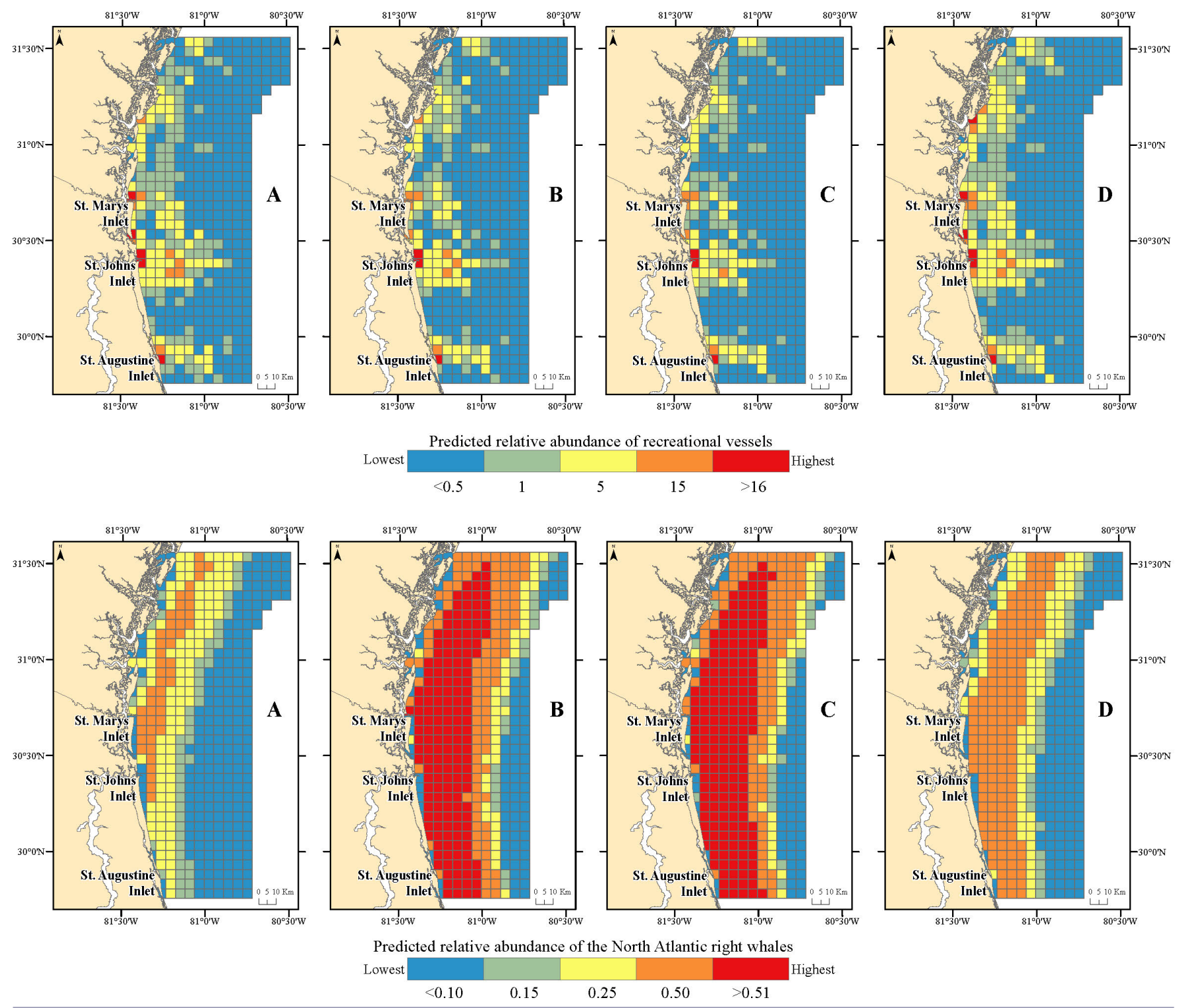

feeding areas by March (Krzystan et al. 2018). These higher values may be related to an increase in the number of recreational vessels using this area in March.

Several authors highlighted the importance of using predictive modeling techniques to examine species distributions rather than relying only on sightings (Guisan et al. 2002, Bauduin et al. 2013, Redfern et al. 2013). The use of spatial modeling techniques helps to account for imperfect detectability and limited coverage of data collection. They also allow for testing the effects of external variables that can be used to make predictions in space or time (Guisan et al. 2002, O'Connor 2002). We used external information (predictor variables) and modeling techniques to produce relative probabilities of occurrence for North Atlantic right whales and for recreational vessels. However, implementation of the modeling method can be time consuming and challenging to apply depending on the expertise of the analyst and/or managers. Furthermore, the modeling method may be limited by the availability of external variables. Other external variables that might influence recreational vessel abundance and distribution could be those related to weather (e.g., rain, cloud coverage, wind speed), regulations (e.g., closed and open season of main target fish species), socioeconomics (e.g., fuel price, boating experience), or situational variables (e.g., vessel length, boating activity). The effect of these variables on the distribution of recreational vessels at different scales should be explored in future studies. 
Fig. 4. Monthly encounter risk (relative probability of a whale and a recreational vessel cooccurring in the same grid cell) for North Atlantic right whales and recreational vessel for December (A), January (B), February (C), and March (D). White dots represent Early Warning System's (EWS) opportunistic reports of interactions between right whale and vessels. Sampling grid cells are $5.56 \mathrm{x}$ $5.56 \mathrm{~km}$ cells $(n=441)$.
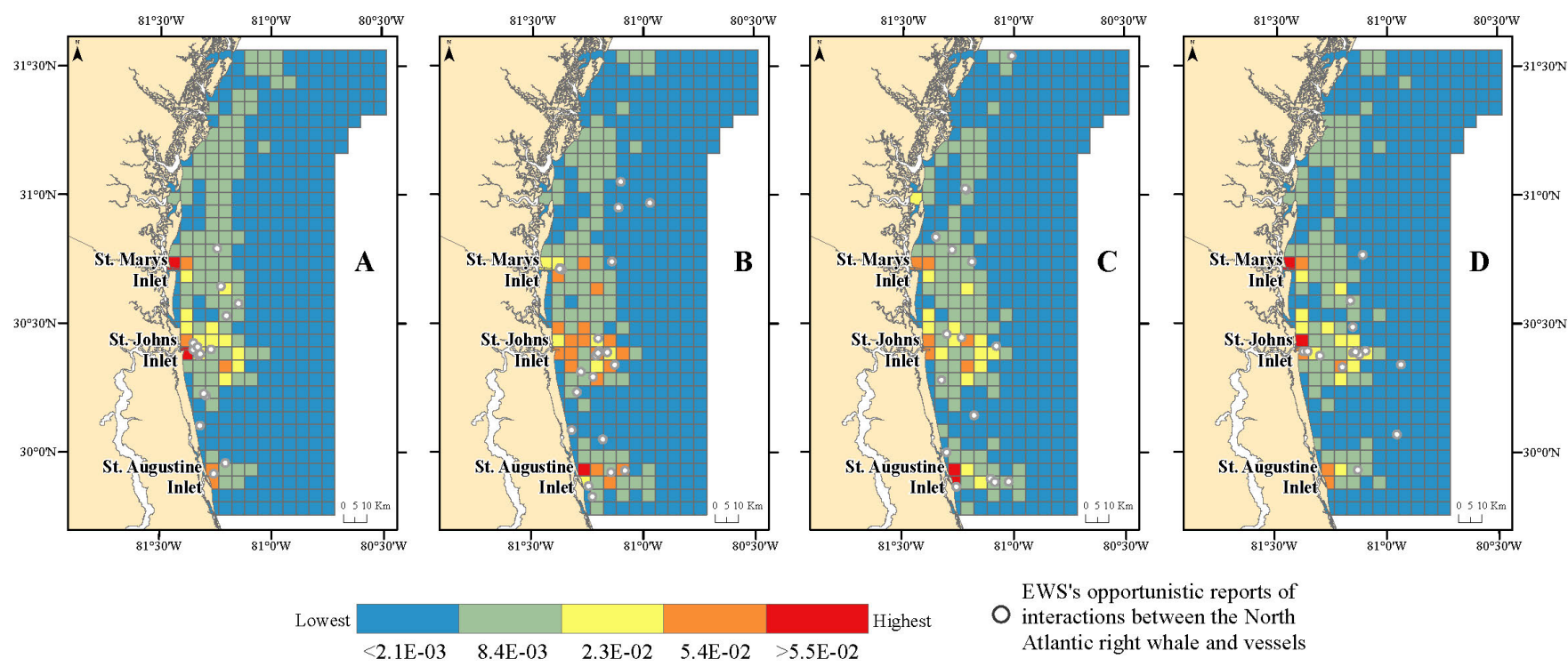

EWS's opportunistic reports of

$O$ interactions between the North

Atlantic right whale and vessels

\section{Management Implications}

In 2014-2015, the EWS protocol was modified so that predictive models of North Atlantic right whale distribution are used to prioritize survey effort in areas expected to maximize whale detections for population monitoring, and mitigating commercial vessel strikes (Surrey-Marsden et al. 2018, see also Hazen et al. 2017). The models developed in this study could also be included in the decision rules for determining where to fly in order to obtain information regarding North Atlantic right whale cooccurrence with recreational vessels and mitigating encounters. While conducting aerial surveys, the EWS team mitigates observed interactions by communicating with vessel operators to inform them about rules regarding North Atlantic right whales and to redirect their course (speed/direction) when whales are sighted nearby to avoid interactions or direct encounters.

The potential impacts of recreational vessel traffic on North Atlantic right whales are poorly understood but may include direct injury and mortality from collisions, behavioral disturbance, and acoustic masking (Clark et al. 2009). Similarly, potential impacts to vessel operators include risk of injury and property damage. Additional research is needed to translate our index of relative risk into quantitative estimates of absolute risk and population impacts (Martin et al. 2016, Pirotta et al. 2018). Estimates of absolute North Atlantic right whale density within the study area (as opposed to relative probabilities of occurrence), which account for imperfect detection due to availability bias (i. e., whales beneath the surface during surveys) and for repeat sightings of individuals, are needed to quantify population impacts. Additional information on the speed, size, and shape of recreational vessels may be used to predict the severity of injury should a collision occur and of noise impacts. Studies of the behavioral response of whales and vessel operators during encounters can be used to estimate energetic consequences for whales and the probability of avoiding collisions. By integrating this information with the spatial distribution of whales and recreational vessels, managers can make better predictions about the effectiveness of potential management actions (Crum et al. 2019, Udell et al. 2019).

Since 1997, it has been illegal to approach and remain within 460 $\mathrm{m}$ (500 yards) of North Atlantic right whales in the United States of America. This regulation becomes even more important in the nursing and calving grounds where mother/calf pairs may be more susceptible to human disturbance (NOAA 1997, National Marine Fisheries Service (NMFS) 2005). However, because of the size of the nursing and calving grounds in the SEUS, the information obtained in these analyses may be used to guide education, management, and law enforcement activities that encourage compliance with this regulation in the study area.

\section{Responses to this article can be read online at: http://www.ecologyandsociety.org/issues/responses. php/11923}

\section{Acknowledgments:}

This work was supported by the Southeast Regional Office NOAA Fisheries Services pursuant to National Oceanic and Atmospheric Administration Award number NAI00R4170079, by the University of Florida, and by the Florida Sea Grant College Program. We would like to thank Barb Zoodsma and all those involved in the Early Warning System for the job that they do and for sharing the data they record on the spatial distribution of right whales and recreational vessels. This project would not be possible without their efforts and support. 


\section{Data Availability:}

The datalcode that support the findings of this study are openly available in [OSF] at [https://osf.iolxnhq7 and https://osf.iol v8yxp].

\section{LITERATURE CITED}

Barton, K., and M. K. Barton. 2015. Mu-MIn: multi-model inference. R Package Version 1.43.17. [online] URL: http://RForge.R-project.org/projects/mumin/

Bauduin, S., J. Martin, H. H. Edwards, O. Gimenez, S. M. Koslovsky, and D. E. Fagan. 2013. An index of risk of cooccurrence between marine mammals and watercraft: example of the Florida manatee. Biological Conservation 159:127-136. https://doi.org/10.1016/j.biocon.2012.10.031

Bohnsack, J. A. 1989. Are high densities of fishes at artificial reefs the result of habitat limitation or behavioral preference? Bulletin of Marine Science 44(2):631-645.

Bohnsack, J. A., and D. L. Sutherland. 1985. Artificial reef research: a review with recommendations for future priorities. Bulletin of Marine Science 37(1):11-39.

Buchanan, C. C. 1973. Effects of an artificial habitat on the marine sport fishery and economy of Murrells Inlet, South Carolina. Marine Fisheries Review 35(9) :15-22.

Chang, Y. J., C. L. Sun, Y. Chen, S. Z. Yeh, and G. Dinardo. 2012. Habitat suitability analysis and identification of potential fishing grounds for swordfish, Xiphias gladius, in the South Atlantic Ocean. International Journal of Remote Sensing 33(23):75237541. https://doi.org/10.1080/01431161.2012.685980

Chion, C., P. Lamontagne, S. Turgeon, L. Parrott, J. A. Landry, D. J. Marceau, C. C. Martins, R. Michaud, N. Menard, G. Cantin, and S. Dionne. 2011. Eliciting cognitive processes underlying patterns of human-wildlife interactions for agent-based modelling. Ecological Modelling 222(14):2213-2226. https://doi. org/10.1016/j.ecolmodel.2011.02.014

Clark, C. W., W. T. Ellison, B. L. Southall, L. Hatch, S. M. van Parijs, A. Frankel, and D. Ponirakis. 2009. Acoustic masking in marine ecosystems: intuitions, analysis, and implication. Marine Ecology Progress Series 395:201-222. https://doi.org/10.3354/ meps08402

Crum, N., T. Gowan, A. Krzystan, and J. Martin. 2019. Quantifying risk of whale-vessel collisions across space, time, and management policies. Ecosphere 10(4): e02713. https://doi. org/10.1002/ecs 2.2713

Dormann, C. F., J. Elith, S. Bacher, C. Buchmannm G. Carl, G. Carré, J. R. Marquéz, B. Gruber, B Lafourcade, P. J. Leitao, and T. Münkemüller. 2013. Collinearity: a review of methods to deal with it and a simulation study evaluating their performance. Ecography 36:27-46. https://doi.org/10.1111/j.1600-0587.2012.07348. $\underline{\mathrm{X}}$

Elwen, S. H., and P. B. Best. 2004. Environmental factors influencing the distribution of southern right whales (Eubalaena australis) on the south coast of South Africa. II: Within bay distribution. Marine Mammal Science 20(3):583-601. https://doi. org/https://doi.org/10.1111/j.1748-7692.2004.tb01181.x
Environmental Systems Research Institute (ESRI). 2018. ArcGIS Desktop: Release 10.6. Environmental Systems Research Institute, Redlands, California, USA.

Farrell, E. R., A. M. Boustany, P. N. Halpin, and D. L. Hammond. 2014. Dolphinfish (Coryphaena hippurus) distribution in relation to biophysical ocean conditions in the northwest Atlantic. Fisheries Research 151:177-190. https://doi.org/10.1016/j. fishres.2013.11.014

Félix, F., and N. Botero-Acosta. 2011. Distribution and behaviour of humpback whale mother-calf pairs during the breeding season off Ecuador. Marine Ecology Progress Series 426:277-287. https://doi.org/10.3354/meps08984

Fonnesbeck, C. J., L. P. Garrison, L. I. Ward-Geiger, and R. D. Baumstark. 2008. Bayesian hierarchichal model for evaluating the risk of vessel strikes on North Atlantic right whales in the SE United States. Endangered Species Research 6(1):87-94. https:// doi.org/10.3354/esr00134

Gowan, T. A., and J. G. Ortega-Ortiz. 2014. Wintering habitat model for the North Atlantic right whale (Eubalaena glacialis) in the southeastern United States. PLoS One 9(4): e95126. https:// doi.org/10.1371/journal.pone.0095126

Guisan, A., T. C. Edwards, Jr., and T. Hastie. 2002. Generalized linear and generalized additive models in studies of species distributions: setting the scene. Ecological Modelling 157(23):89-100. https://doi.org/10.1016/S0304-3800(02)00204-1

Haviland-Howell, G., A. S. Frankel, C. M. Powell, A. Bocconcelli, R. L. Herman, and L. S. Sayigh. 2007. Recreational boating traffic: a chronic source of anthropogenic noise in the Wilmington, North Carolina Intracoastal Waterway. The Journal of the Acoustical Society of America 122(1):151-160. https://doi. org/10.1121/1.2717766

Hazen, E. L., D. M. Palacios, K. A. Forney, E. A. Howell, E. Becker, A. L. Hoover, L. Irvine, M. DeAngelis, S. J. Bograd, B. R. Mate, and H. Bailey. 2017. WhaleWatch: a dynamic management tool for predicting blue whale density in the California Current. Journal of Applied Ecology 54(5):1415-1428. https://doi.org/10.1111/1365-2664.12820

Hourigan T. F., J. K. Reed, S. Pomponi, S. W. Ross, A. W. David, and S. Harter. 2017. State of deep-sea coral and sponge ecosystems of the southeast United States. Pages 407-467 in T. F. Hourigan, P. J. Etnoyer, and S. D. Cairns, editors. The state of deep-sea coral and sponge ecosystems of the United States. National Oceanic and Atmospheric Administration (NOAA) Technical Memorandum NMFS-OHC-4, Silver Spring, Maryland, USA. [online] URL: https://deepseacoraldata.noaa. gov/library\#c12=\&b_start $=0$

Krzystan, A. M., T. A. Gowan, W. L. Kendall, J. Martin, J. G. Ortega-Ortiz, K. Jackson, A. R. Knowlton, P. Naessig, M. Zani, D. W. Schulte, and C. R. Taylor. 2018. Characterizing residence patterns of North Atlantic right whales in the southeastern USA with a multistate open robust design model. Endangered Species Research 36:279-295. https://doi.org/10.3354/esr00902

Lagueux, K. M., M. A. Zani, A. R. Knowlton, and S. D. Kraus. 2011. Response by vessel operators to protection measures for right whales Eubalaena glacialis in the southeast US calving 
ground. Endangered Species Research 14(1):69-77. https://doi. org/10.3354/esr00335

Laist, D. W., A. R. Knowlton, J. G. Mead, A. S. Collet, and M. Podesta. 2001. Collisions between ships and whales. Marine Mammal Science 17(1):35-75. https://doi.org/10.1111/j.1748-7692.2001. $\underline{\mathrm{tb} 00980 . \mathrm{x}}$

Lundquist, D., M. Sironi, B. Würsig, V. Rowntree, J. Martino, and L. Lundquist. 2013. Response of southern right whales to simulated swim-with-whale tourism at Península Valdés, Argentina. Marine Mammal Science 29(2): E24-E45. https://doi. org/10.1111/j.1748-7692.2012.00583.x

Lusseau, D. 2005. Residency pattern of bottlenose dolphins Tursiops spp. in Milford Sound, New Zealand, is related to boat traffic. Marine Ecology Progress Series 295:265-272. https://doi. org/10.3354/meps295265

Maloney, E. D., and D. B. Chelton. 2006. An assessment of the sea surface temperature influence on surface wind stress in numerical weather prediction and climate models. Journal of Climate 19(12):2743-2762. https://doi.org/10.1175/JCLI3728.1

Marra, G., and S. N. Wood. 2011. Practical variable selection for generalized additive models. Computational Statistics and Data Analysis 55(7):2372-2387. https://doi.org/10.1016/j.csda.2011.02.004

Martin, J., Q. Sabatier, T. A. Gowan, C. Giraud, E. Gurarie, C. S. Calleson, J. G. Ortega-Ortiz, C. J. Deutsch, A. Rycyk, and S. M. Koslovsky. 2016. A quantitative framework for investigating risk of deadly collisions between marine wildlife and boats. Methods in Ecology and Evolution 7(1):42-50. https://doi. org/10.1111/2041-210X.12447

Montes, N., R. Swett, C. Sidman, and T. Fik. 2016. Offshore recreational boating characterization in the southeast US. Florida Sea Grant TP-226. Florida, USA. [online] URL: https:// https:// www.flseagrant.org/wp-content/uploads/Tp 226 web.pdf.

Montes, N., R. Swett, and R. Ahrens. 2018a. Modeling the spatial and seasonal distribution of offshore recreational vessels in the southeast United States. PLoS One 13(11): e0208126. https://doi. org/https://doi.org/10.1371/journal.pone.0208126

Montes, N., R. Swett, S. K. Jacobson, and C. Sidman. $2018 b$. Factors influencing recreational boaters' intentions to comply with right whale regulations in the southeastern United States. Society and Natural Resources 31(4):473-488. https://doi.org/ https://doi.org/10.1080/08941920.2017.1377795

National Marine Fisheries Service (NMFS). 2005. Recovery plan for the North Atlantic right whale (Eubalaena glacialis). NMFS, Silver Spring, Maryland, USA. [online] URL: https://repository. library.noaa.gov/view/noaa/3411

National Oceanic and Atmospheric Administration (NOAA). 1997. North Atlantic right whale protection. 500 yardrule approach. 62 FR6729. U.S. Department of Commerce, Washington, D.C., USA. [online] URL: https://www.govinfo.gov/content/pkg/ FR-1997-02-13/pdf/97-3632.pdf

O'Connor, R. J. 2002. The conceptual basis of species distribution modeling: time for a paradigm shift. Predicting species occurrences: issues of accuracy and scale. Island Press, Washington, D.C., USA.
Pebesma, E. J. 2004. Multivariable geostatistics in S: the gstat package. Computers and Geosciences 30:683-691. Version 2.0-6. [online] URL: https://cran.r-project.org/web/packages/gstat/ index.html https://doi.org/10.1016/j.cageo.2004.03.012

Pennino, M. G., M. A. P. Roda, G. J. Pierce, and A. Rotta. 2016. Effects of vessel traffic on relative abundance and behaviour of cetaceans: the case of the bottlenose dolphins in the Archipelago de La Maddalena, north-western Mediterranean Sea. Hydrobiologia 776(1):237-248. https://doi.org/10.1007/s10750-016-2756-0

Peterson, B. G., P. Carl, K. Boudt, R. Bennett, J. Ulrich, E. Zivot, ... and D. Wuertz. 2018. Package 'Performance Analytics'. Version 2.0.4. R Team Cooperation. [online] URL: https://cran. r-project.org/web/packages/PerformanceAnalytics/PerformanceAnalytics. pdf

Pettis, H. M., R. M. Pace, III, and P. K. Hamilton. 2018. North Atlantic Right Whale Consortium 2018 annual report card. The North Atlantic Right Whale Consortium, Boston, Massachusetts, USA. [online] URL: https://www.narwc.org/uploads/1/1/6/6/116623219/2018report cardfinal.pdf

Pirotta, E., M. Mangel, D. P. Costa, B. Mate, J. A. Goldbogen, D. M. Palacios, L. A. Hückstädt, E. A. McHuron, L. Schwarz, and L. New. 2018. A dynamic state model of migratory behavior and physiology to assess the consequences of environmental variation and anthropogenic disturbance on marine vertebrates. The American Naturalist 191(2):E40-E56. https://doi.org/10.1086/695135

Radlinski, M. K., M. A. Sundermeyer, J. J. Bisagni, and S. X. Cadrin. 2013. Spatial and temporal distribution of Atlantic mackerel (Scomber scombrus) along the northeast coast of the United States, 1985-1999. ICES Journal of Marine Science 70 (6):1151-1161. https://doi.org/https://doi.org/10.1093/icesjms/fst029

Redfern, J. V., M. F. McKenna, T. J. Moore, J. Calambokidis, M. L. Dengelis, E. A. Becker, J. Barlow, K. A. Forney, P. C. Fiedler, and S. J. Chivers. 2013. Assessing the risk of ships striking large whales in marine spatial planning. Conservation Biology 27 (2):292-302. https://doi.org/10.1111/cobi.12029

Rolland, R. M., S. E. Parks, K. E. Hunt, M. Castellote, P. J. Corkeron, D. P. Nowacek, S. K. Wasser, and S. D. Kraus. 2012. Evidence that ship noise increases stress in right whales. Proceedings of the Royal Society 279(1737):2363-2368. https:// doi.org/10.1098/rspb.2011.2429

Rowntree, V. J., R. S. Payne, and D. M. Schell. 2001. Changing patterns of habitat use by southern right whales (Eubalaena australis) on their nursery ground at Península Valdés, Argentina, and in their long-range movements. Journal of Cetacean Research and Management 2(Special Issue):133-143. https://doi.org/ https://doi.org/10.47536/jcrm.vi.298

Salden, D. R. 1988. Humpback whale encounter rates offshore of Maui, Hawaii. The Journal of Wildlife Management 52(2):301304. https://doi.org/10.2307/3801238

Sharp, S. M., W. A. McLellan, D. S. Rotstein, A. M. Costidis, S. G. Barco, K. Durham, T. D. Pitchford, K. A. Jackson, P. Y. Daoust, T. Wimmer, and E. L. Couture. 2019. Gross and histopathologic diagnoses from North Atlantic right whale Eubalaena glacialis mortalities between 2003 and 2018. Diseases of Aquatic Organisms 135(1):1-31. https://doi.org/https://doi. org/10.3354/dao03376 
Shimada, T., and H. Kawamura. 2006. Satellite observations of sea surface temperature and sea surface wind coupling in the Japan Sea. Journal of Geophysical Research: Oceans 111(C8): C08010. https://doi.org/10.1029/2005JC003345

Sidman, C. F., and T. J. Fik. 2005. Modeling spatial patterns of recreational boaters: vessel, behavioral, and geographic considerations. Leisure Sciences 27(2):175-189. https://doi. org/10.1080/01490400590912079

Sidman, C., T. Fik, R. Swett, B. Sargent, J. Fletcher, S. Fann, D. Fann, and A. Coffin. 2007. A recreational boating characterization of Brevard County. Florida Sea Grant TP-160. Florida, USA. [online] URL: https://ufdc.ufl.edu/IR00004291/00001

Smultea, M. A. 1994. Segregation by humpback whale (Megaptera novaeangliae) cows with a calf in coastal habitat near the island of Hawaii. Canadian Journal of Zoology 72(5):805-811. https://doi.org/10.1139/z94-109

Surrey-Marsden, C., C. Accardo, M. White, C. George, T. Gowan, P. Hamilton, K. Jackson, J. Jakush, T. Pitchford, C. Taylor, L. Ward, and B. Zoodsma. 2018. North Atlantic right whale calving area surveys: 2016/2017 results. United States Department of Commerce, National Oceanic and Atmospheric Administration (NOAA). NOAA Technical Memorandum NMFS-SER-8, USA. [online] URL: https://repository.library.noaa.gov/view/noaa/19250

Timmel, G., S. Courbis, H. Sargeant-Green, and H. Markowitz. 2008. Effects of human traffic on the movement patterns of Hawaiian spinner dolphins (Stenella longirostris) in Kealakekua Bay, Hawaii. Aquatic Mammals 34(4): 402. https://doi. org/10.1578/AM.34.4.2008.402

Udell, B. J., J. Martin, R. J. Fletcher, M. Bonneau, H. H. Edwards, T. A Gowan, S. K. Hardy, E. Gurarie, C. S. Calleson, and C. J. Deutsch, 2019. Integrating encounter theory with decision analysis to evaluate collision risk and determine optimal protection zones for wildlife. Journal of Applied Ecology 56: 10501062. https://doi.org/10.1111/1365-2664.13290

Vanderlaan, A. S., J. J. Corbett, S. L. Green, J. A. Callahan, C. Wang, R. D. Kenney, C. T. Taggart, and J. Firestone. 2009. Probability and mitigation of vessel encounters with North Atlantic right whales. Endangered Species Research 6(3):273-285. https://doi.org/10.3354/esr00176

Vermeulen, E., A. Cammareri, and L. Holsbeek. 2012. Alteration of southern right whale (Eubalaena australis) behaviour by human-induced disturbance in Bahía San Antonio, Patagonia, Argentina. Aquatic Mammals 38(1): 56. https://doi.org/10.1578/ AM.38.1.2012.56

Wall, C. C., F. E. Muller-Karger, and M. A. Roffer. 2009. Linkages between environmental conditions and recreational king mackerel (Scomberomorus cavalla) catch off west-central Florida. Fisheries Oceanography 18(3):185-199. https://doi.org/10.1111/ j.1365-2419.2009.00507.x

Ward-Geiger, L. I., G. K. Silber, R. D. Baumstark, and T. L. Pulfer. 2005. Characterization of ship traffic in right whale critical habitat. Coastal Management 33(3):263-278. https://doi. org/10.1080/08920750590951965
Watkins, W. A. 1986. Whale reactions to human activities in Cape Cod waters. Marine Mammal Science 2(4):251-262. https://doi. org/10.1111/j.1748-7692.1986.tb00134.x

Williams, R., and P. O’Hara. 2010. Modelling ship strike risk to fin, humpback and killer whales in British Columbia, Canada. Journal of Cetacean Research and Management 11(1):1-8.

Wood, S. N. 2001. mgcv: GAMs and generalized ridge regression for R. $R$ news 1(2):20-25. [online] URL: https://cran.r-project. org/web/packages/mgcv/mgcv.pdf

Wood, S. N. 2006. Generalized additive models: an introduction with $R$. Chapman and Hall/CRC. Boca Raton, Florida, USA.

Zuur, A. F. 2012. A beginner's guide to generalized additive models with $R$. Highland Statistics Limited. Newburgh, New York, USA. 